\title{
The Behavior of Bureaucratic Apparatus the State Civil Apparatus Placement in the Parigi Moutong District, Central Sulawesi Province
}

\author{
Suasa $^{1}$, Syamsul Bachri ${ }^{2}$, Mustainah $^{3}$, Nasir Mangngasing ${ }^{4}$, Mohammad Riski Borman ${ }^{5}$ \\ suasa_ambo@yahoo.com ${ }^{1}$, mustainahmappatoba@gmail.com ${ }^{2}$, mohriskiborman1@gmail.com ${ }^{3}$ \\ Universitas Tadulako, Department of Public Administration, Faculty of Sosial and Political Science, \\ Tadulako University, Palu, Central Sulawesi, Indonesia, $94118^{123}$
}

\begin{abstract}
The behavior of the bureaucratic apparatus in the placement of some echelon II, III, and IV positions of the State Civil Apparatus in Parigi Moutong District is still based on kinship relations and political services. This study aims to examine and analyze the behavior of bureaucratic apparatus and the implementation of employee placement in carrying out their main tasks and functions during one period of governance year 2013 2018. Qualitative descriptive research methods are used to describe the phenomena occurred in the field. Data collection is done through observation, interviews, and documentation analysis. The result shows that the bureaucratic apparatus behavior of employee placement in that period was (1) Care, does not fully followed. (2) Excellence, was not effective. (3) Transformative, does not achieved. (4) Professionals, still less professional. (5) Integrity, does not effectively implemented. (6) Vision of novelty does not achieved and (7) democratic governance agent does not maximize.
\end{abstract}

Keywords: Apparatus, Behavior, Bureaucracy, Government, Placement, Politic.

\section{Introduction}

State civil apparatus is a profession that is demanded by many people who are expected to have good dedication, commitment to serve, and also protecting the civil society [1]. Nowadays, one of the big challenges faced by the government, especially local government is how to carry out professional, ethical, competitive advantage, and ability to hold firm in carrying out their duties and functions, fulfill people aspirations, and free from Collusion, Corruption, and Nepotism in the governance process [2]. Moreover, bureaucratic reform in Indonesia took a new round when government launched the grand design of national bureaucratic reform through Presidential Regulation No. 81 year 2010, thus bureaucratic reform efforts can be more directed and sustainable.

The ideal type of organization called bureaucracy as a form that is accepted and applied by government agencies [3]. Bureaucratic apparatus behavior is a systematic, integrated, and comprehensive process or effort, aims at realizing good governance and an instrument for the operation of an administration, where administrative behavior works based on division of work, hierarchical, authority, relationship impersonality, behavioral regulation, and technical capability in carrying out their duties and functions as administering government administration [4]. Organizational behavior is a study involving human behavior aspects in an organization or a particular group [5]. 
The government process in Parigi Moutong District has not run effectively yet due to the unprofessionalism of the civil servant or employees in carrying out their main duties and functions. This is due to scientific competence and expertise which should be one of the benchmarks in the placement of bureaucrats, have yet become major consideration in the placement of civil servants in the district. In reality and rationality, the placement of structural officials (echelon II, echelon III, and echelon IV) in the government bureaucracy does not fully apply the terms of state civil apparatus placement in accordance with state civil apparatus law number 5 year 2014 and presidential regulations number 11 year 2017 about civil apparatus management. It is because of the interference of the political interests of public officials in influencing the positions composition in the structural ranks and behavior of government bureaucracies. Parigi Moutong District government is one of the areas where organizational behavior does not run fully effectively due to the involvement interest. The phenomenon occurs in the placement of officials in the bureaucratic structure is still based on two considerations, namely political services and kinship relations as the implication of influence and services of politician during regional head election.

Based on the conceptuality, topic regarding the behavior of bureaucratic apparatus is interesting to be discussed as a reference to explain about the phenomenon of the existence of public officials in the government. Therefore, this research is examining the title regarding the behavior of bureaucratic apparatus in the placement of the State civil apparatus in Parigi Moutong District, Central Sulawesi Province. Moreover, this research aims to determine the behavior of bureaucratic apparatus in Parigi Moutong District and find out the implications of employee placement in carrying out their main duties and functions in the district government.

\section{Methodology}

This research was conducted in Parigi Moutong District, Central Sulawesi Province. The research method uses qualitative descriptive approach. This approach intends to describe the relation of an event to obtain an overview of the phenomena that occur in the field [6]. According to [7] qualitative descriptive method can be interpreted as the problem solving process that is investigated by describing the subjective or objective conditions of research, institutions, society, and others - based on facts and concepts. The observation focuses on the behavioral characteristics of the bureaucratic apparatus in the state civil apparatus placement, then, informants from echelon II, III, and IV in the regional government. Research instrument uses interview guidelines. The data collection technique uses an inventory of primary and secondary data. The data analysis technique uses the data analysis process schema from [8]:

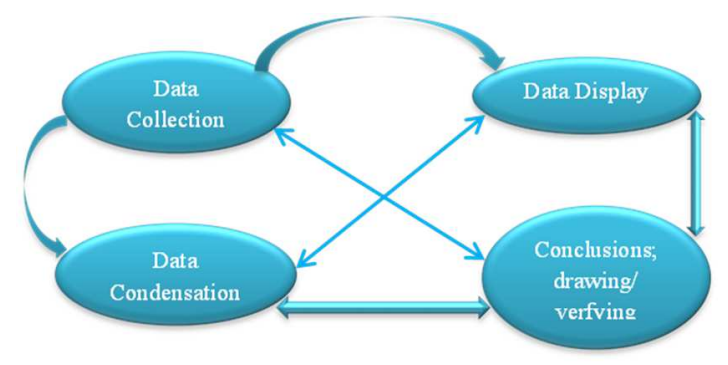

Fig. 1. Data analysis process schema 
Based on Figure 1, the data condensation component and data presentation are carried out together with the data collection process, after the data collected, the three components of analysis (data condensation, display, and conclusions drawing or verification) are integrated:

- Data condensation

Process of selecting, extracting, and/or transforming data that approaches the entire section of written field notes, interview transcripts, documents, and other empirical materials.

- Data display

The basic reason for this stage is to simplify complex information into simplified form units and configurations to make it understandable, thus, all of the data is designed to combine information that is arranged in a coherent form to understand the existing phenomena compared to theories.

- Conclusion or verification

The process of searching for the meaning of objects, noting regularities, patterns, explanations, possible configurations, causal pathways, and research propositions.

\section{Result}

Behavior in government management is a fairly actual approach, even though it is actually as a reaction of the servant behavior in various organizational structures in response to inequality, conflict, and problems that arise in the interaction of every layer of society and organizations, both public organizations and private organizations. Moreover, The development of human resources and other resources should not stand alone, but rather synergistically enhanced through a resource plan that is interconnected each other [9][10].

Civil servant placement is related to matching a person with a position that he will hold based on the knowledge, skills, and personality, with the principle of the right man and the right place to survive, adapt, and grow within the organization [11][12]. Parigi Moutong is one of the regions in Indonesia that organizational behavior has not been effective due to there is interest involved. The phenomenon occurs that there are some structural officials or state civil apparatus positions is not in accordance with their scientific competence and expertise that should become the benchmark in the placement of bureaucrats in occupying positions.

Based on the interview result with some important interviewees in the regional staffing agency in Parigi Moutong District, they said that the placement of structural positions been in accordance with state civil apparatus law number 5 year 2014 and presidential regulation number 11 year 2017 about Civil Servants Management. However, based on the interview with expert staff and other department head, it is found that the employee placement currently does not fully meet their scientific qualification, scientific competence, experience, and expertise, which is still influenced by political factors and kinship, especially the echelon position in the technical office. Thus, still unbalanced information among the interviewees.

According to the presidential regulation number 11 year 2017, the requirements to be appointed as senior leadership positions are (1) having a minimum undergraduate education qualification or Diploma IV, (2) having technical, managerial, and cultural social competencies according to job competency standards determined, (3) having experience in the certain position that related to the field of duty that will be occupied cumulatively for at least 5 (five) years, (4) being or has held an administrator position or functional position for a 
minimum of 2 (two) years, (5) have a good track record of position, integrity, and morality, (6) maximum age of 56 years, and (7) physically and mentally healthy.

Table 1. State Civil Apparatus Recapitulation Data Based On the Education Qualification of the Structural Officer (Echelon)

\begin{tabular}{|c|c|c|c|c|c|c|c|}
\hline Position & Grade & Echelon & $\mathrm{PhD}$ & Magister & Bachelor & Diploma & High School \\
\hline \multirow[t]{2}{*}{ HLP } & Pratama & II.a & & & 1 & & \\
\hline & & II.b & & 14 & 18 & & \\
\hline \multirow[t]{5}{*}{ Administration } & Administrator & III.a & & 15 & 45 & 1 & 1 \\
\hline & & III.b & & 36 & 85 & 4 & 3 \\
\hline & Inspector & IV.a & & 71 & 440 & 26 & 44 \\
\hline & & IV.b & & & 51 & 3 & 4 \\
\hline & Total & & & 136 & 640 & 34 & 52 \\
\hline
\end{tabular}

Table 1. [21] shows that a person in administrative positions who occupy administrator level (echelon III/a) only have high school graduate and 3 (three) people in echelon III/b position only have high school educational qualification. In the supervisory level, there are 44 (forty four) people in echelon IV/a position who only have high school graduate and 4 (four) people in echelon IV/b position with high school qualification as well. There are some people who have high school education qualification can occupy administrator and inspector positions, which means it does not follow the presidential regulation number 11 year 2017 about civil servant management which state that the academic qualification of administrator and inspector positions should have minimum diploma degree, not only high school graduate.

Table 2. Civil Servants Recapitulation Data Based On Structural Position (Echelon) and Grade In Parigi Moutong District Government

\begin{tabular}{ccccccccccc}
\hline Position & Level & Echelon & \multicolumn{9}{c}{ Grade } & \multicolumn{3}{c}{ Total } \\
\cline { 3 - 8 } & & & III/a & III/b & III/c & III/d & IV/a & IV/b & IV/c & \\
\hline HLP & Pratama & II.a & & & & & & & 1 & 1 \\
& & II.b & & & & & & 7 & 25 & 32 \\
\multirow{3}{*}{ Administration } & Administrator & III.a & & & & 3 & 23 & 36 & & 62 \\
& & III.b & & & 3 & 48 & 69 & 8 & & 128 \\
& Inspector & IV.a & 2 & 66 & 283 & 211 & 18 & 1 & & 581 \\
& & IV.b & 12 & 41 & 4 & 1 & & & & 58 \\
& \multirow{2}{*}{ Total } & & 14 & 107 & 290 & 263 & 110 & 52 & 26 & 862 \\
\hline
\end{tabular}

Table 2. [22] shows that there is a person with grade IV/b still placed in echelon IV/a position, while there are another grade IV/b occupying echelon II/b, III/a, and III/b positions. Some people with grade IV/a placed in echelon IV/a position, while there are another grade IV/a who occupied in echelon III/a and III/b positions, of which there are up to 23 people in echelon III/a position, while there are 18 people still placed in echelon IV/a position. Moreover, a person with grade III/d still placed in echelon IV/b position, while there are 
another grade III/d who occupied in echelon III/a, III/b, and IV/a positions. There are employees or apparatus who have lower grade could occupy higher echelon position while there are some people have stagnant position. Therefore, the apparatus behavior of the structural officials placement in the Parigi Moutong District government still looks less effective.

\section{Discussion}

\subsection{The behavior of bureaucratic apparatus in parigi moutong distric government, central sulawesi province}

According to [13], bureaucratic figures and employees should be: (1) caring, (2) superior, (3) transformative, (4) professional, (5) having integrity, (6) have innovative vision, and (7) democratic government agents, as explained below:

Caring. Caring is that the bureaucratic apparatus must be able to encourage changes in the institutions by distributing access to the vertical mobility resources.

Education. Caring in terms of education does not follow the minimum level of education or competence, both formal and non-formal education, as well as grades, years of service, and experience is not in accordance with the regulation criteria number 11 year 2017, however, some of the appointment of position placement currently still based on kinship with the leader. As a result, government administration become less effective, regional development do not optimal, and the potential for collusion, corruption and nepotism may increase.

Year of Service. Based on the interview result with informants, it found that the year of service has not become one of the main requirement where there are found some subordinates have higher grade than the leader or head department.

Excellent. Bureaucratic apparatus has to be more excellent compared with ordinary people, like achievement and services in increasing competitiveness for future development.

Excellence in Achievement. Based on the interview result with informants, it found that this aspect in some of regional officials' positions still considered to be unsatisfactory. Moreover, there were employees who only placed in their previous position for less than 2 (two) years, thus did not have outstanding performance or achievements during their tenure.

Excellence in Service. Based on the interview result, it found that this aspect still considered do not satisfying due to there are certain operational department does not have proper operational funds, some are deficient and some are excess. Therefore, the department with less operational funds provided (then it should be) could not afford to provide maximum service.

Transformative. The evaluation aspects follows [14] characteristics. Based on the interview, it found that a leader in certain offices as someone who cares and helpful does not achieved, it shown during daily interaction of the leader with the subordinates in the department.

Professional. The government bureaucracy must have the courage to set a minimum standard of apparatus education [16]. Based on interview result, it found that education or managerial 
skills of certain department leader still less professional due to the placement of employees or officials was partly incompatible with his education or competence. As example, technical office head position occupied by employees who have a social education background

Integrity. Based on the interview result with informants, it was found that the integrity related to values of justice, truth, and humanity was not achieved yet some of the official leaders were chosen based on family and kinship relation, and political services with the leader.

Novelty of Vision. Based on interview result, it found that the novelty of vision does not succesfully carried out. It can be seen in the condition of Sail Tomini tourism destination in the district area which does not fully utilized. The destination does not produce sustainable output for tourism purposes which does not meet the purpose of establishing the area.

Agent Democratic Governance. Based on the interview, it found that this aspect still less successful due to several technical offices was occupied by different background officials. The future bureaucracy needs to have the characteristics of caring, professional, acting as an agent of reform, and contributing to the realization of democratic government [15].

\subsection{The implications of employees placement in parigi moutong district, central sulawesi province}

[17] said that placement is the assignment of employee or civil servant in his new job, there are 3 (three) important types of placement, namely promotion, transfer, and demotion:

Promotions. The evaluation aspect follows [18] types of promotions explanation. Based on the observations and interviews, it found that someone who was promoted to occupy a certain position was not merely based on achievement and seniority. As example, someone occupying an official or agency position is not chosen based on their area of expertise. It found that there are subordinates who have higher grade compared with the head of agency or department.

Transfer. [19] explain in detail about transfer. Based on the observations and interviews result, it found that sometimes there were employees who were transferred due to political factors as a result of direct regional head elections. For example, official or employee who is transferred to a remote area and/or certain agency position to a less productive position.

Demotion. Demotion rarely produce positive results for an employee, this demotion is used as a subtle way to fire an employee or make the employee to propose resignation [20]. Based on observation and interview result, it found that there were number of echelon officials in structural positions transferred or relieved from their duties and responsibilities of the previous position as the political implication of direct regional head election.

\section{Conclusion}

The behavior of the bureaucratic apparatus in Parigi Moutong District of Central Sulawesi Province in the decision making process regarding several important matters related to regulations and employee placement is still slow and compartmentalized to certain people who have special relations with the leader. Moreover, it found that there is still a lack of equitable 
distribution of budgets in each regional apparatus organization, increasing the dependency of subordinates to the head, and showing more loyalty to a personal than the organization.

The governance process does not run the leadership process in the effective and efficient way yet due to unprofessional bureaucracy apparatus in carrying out the duties, functions, and responsibilities in the structural position placement. It is shown that the position appointment currently does not fully in accordance with the scientific competence, education, experience, and years of service which should be one of the assessment benchmarks in appointing structural or institution official or head, so that the placement of employees or officials does not yet apply the principle of the right man and the right place in certain position.

The behavior of bureaucratic apparatus in the government still has lack of characteristics of being caring, excellence, transformative, professional, integrity, novelty of vision, and democratic government agents of the employees' placement in structural positions and lack of humanitarian consideration in human resources in promotion, transfer, and demotion. 


\section{References}

[1] Sufianto, D.: Pengantar Ilmu Pemerintahan. Bandung: CV Pustaka Setia (2015)

[2] Hardiyansyah: Kualitas Pelayanan Publik: Konsep, Dimensi, Indikator, dan Implementasinya. Yogyakarta: Gava Media (2011)

[3] Weber, M.: The Theory of Economics and Social Organization. (A. M. Henderson, \& T. Parsons, Trans.) New York: Oxford University (1947)

[4] Ndraha, T.: Kybernology Ilmu Pemerintahan Baru. Jakarta: Rinake Cipta (2003)

[5] Thoha, M., \& Darma, A.: Membangun Birokrasi Pemerintahan di Era Otonomi Daerah. Jakarta: PT. Raja Grafindo Persada (2000)

[6] Creswell, J. W.: Research Design, Qualitative, Quantitative, and Mixed Methods Approaches, (4th ed.). (A. Fawaid, \& R. K. Pancasari, Trans.) Yogyakarta: Pustaka Pelajar (2016)

[7] Denzin, N. K., \& Lincoln, Y. S.: The Sage Handbook of Qualitative Research 2 (3rd ed.). (Dariyatno, Trans.) Yogyakarta: Pustaka Pelajar (2011)

[8] Miles, M. B., Huberman, A. M., Saldana, J.: Qualitative Data Analysis: A Methods Sourcebook (3rd Edition ed.). United States: SAGE Publications, Inc. (2014)

[9] Edison, E., Anwar, Y, \& Komariyah, I.: Manajemen Sumber Daya Manusia: Strategi Dan Perubahan Dalam Rangka Meningkatkan Kinerja Pegawai Dan Organisasi. Bandung: Alfabeta (2016)

[10] Warren, B., \& Mische, M.: Organisasi Abad Ke 21 Reinventing melalui Reengineering. (I. Andriani, Trans.) Jakarta: PT. Binaman Presindo (1995)

[11] Noe, R. A., Holenbeck, J. R., Gerhart, B., \& Wright P M.: Human Resources Management: Gaining Competitive Advantage (3rd International Edition ed.). California: McGraw-Hill Inc. (2000)

[12] Matthews, G. R.: The Right Man and The Right Place. Kentucky: The University Press of Kentucky (2005)

[13] Dwiyanto, A.: Reformasi Birokrasi Kontekstual, Kembali Ke Jalur Yang Benar. Yogyakarta: Gajahmada University Press (2015)

[14] Syafiie, I. K.: Sistem Administrasi Negara (7th ed.). Jakarta: Remaja Rosdakarya (2014)

[15] Djatmiko, Y. H.: Perilaku Organisasi. Bandung: Alfabeta (2008)

[16] Ekaningsih, A. S.: The Role of Training, Education, and Competency in Improving Apparatus Human Resources Quality. Journal of Borneo Administrator, 9, 189 - 207 (2013)

[17] Milton, C. R.: Human Behavior In Organization: Three Level of Behavior. United States: Prentice Hall Inc. (1981)

[18] Judge, T. A., \& Robbins, S. P.: Perilaku Organisasi: Organizational Behavior (16th Ed.). (R. Saraswati, Trans.). Jakarta: Salemba Empat (2015)

[19] Widodo, J.: Membangun Birokrasi Berbasis Kinerja (3rd ed.). Malang: Bayumedia (2007)

[20] Mustafa, D.: Birokrasi Pemerintahan. Bandung: Alfabeta (2013)

[21] Badan Kepegawaian dan Pengembangan Sumber Daya Manusia.: Rencana Strategis (Restra) Badan Kepegawaian dan Pengembangan Sumber Daya Manusia Tahun 2018 - 2023 Kabupaten Parigi Moutong. Parigi Moutong: BKPSDM (2018) 